\title{
Pengaruh Perbandingan Daging Ayam dan Tepung Kecambah Kacang Merah (Phaseolus Vulgaris L.) terhadap Karakteristik Bakso
}

\section{Effect of The Ratio of Chicken Meat and Red Bean Sprouts Flour (Phaseolus Vulgaris L.) on The Characteristics of Meatballs}

\author{
Arina Ulyani ${ }^{1}$, Ni Wayan Wisaniyasa ${ }^{1 *}$, I Gusti Ayu Ekawati ${ }^{1}$ \\ Program Studi Teknologi Pangan, Fakultas Teknologi Pertanian, Universitas Udayana \\ Kampus Bukit Jimbaran, Badung-Bali \\ *Penulis korespondensi: Ni Wayan Wisaniyasa, Email: wisaniyasa@unud.ac.id
}

\begin{abstract}
This study aimed to determine the effect of the ratio of chicken meat and red bean sprouts flour to the characteristics of the meatballs and to determine the appropriate ratio of chicken meat and red bean sprouts flour to get the best meatball characteristic. This studyused the completely randomized design, with ratio of chicken meat and red bean sprout flour treatmen consisted 5 level, namely (B0) 100\%: 10\%, (B1) 90\%: 10\%, (B2) 80\%: 20\%, (B3) 70\% : 30\%, (B4) 60\%: 40\%. Each treatment was repeated 3 times, in order to obtain 15 experimental units. The data obtained were using analysis of variance and if the treatment had a significant effect, it was continued with the Duncan Multiple Range Test. The results showed that the ratio of chicken meat and red bean sprouts flour had an effect on moisture content, fat content, crude fiber content, texture, hedonic, aroma, taste, texture, and overall acceptance. And scoring on color, taste, and texture. The meatball with a ratio of chicken meat and red bean sprout flour of $90 \%: 10 \%$ was the best meatball characteristics with the criteria: water content of $68.86 \%$, protein content of $23.22 \%$, fat content of $8.03 \%$, crude fiber content of $32.35 \%$, texture $6.63 \mathrm{~N}$, color sensory test, aroma, taste, texture, and overall acceptance are liked.
\end{abstract}

Keywords: meatball, red bean sprout flour, chicken meat

\section{PENDAHULUAN}

Di negara Indonesia banyak sekali macammacam makanan khas Nusantara, salah satunya yaitu bakso. Bakso merupakan salah satu kuliner yang tidak bisa dipisahkan dari lidah orang Indonesia, rasa kuah kaldunya yang gurih dengan perpaduan bola daging yang lezat membuat kuliner bakso ini kian banyak diminati oleh masyarakat. Salah satu bahan utama bakso yang memiliki harga terjangkau ialah daging ayam. Menurut Irmawaty (2016) daging ayam mempunyai kelebihan dalam pembuatan bakso karena memiliki serat yang pendek sehingga tidak alot ketika dimakan dan mudah dicerna oleh tubuh. Menurut Rahmadani (2019), daging ayam broiler segar bagian dada memiliki kadar abu 1,23\%, kadar protein 19,54\%, kadar lemak 12,12\%, kadar kolesterol 2,77\%, kadar air $66,32 \%$, kadar karbohidrat $0,79 \%$ dan serat kasar 4,68\%.

Dalam pembuatan bakso diperlukan bahan campuran agar dapat dihasilkan produk bakso dengan kualitas yang baik. Bahan campuran yang sangat sering digunakan ialah tepung terigu dan tapioka, kedua tepung ini membantu dalam membuat tekstur bakso yang empuk sekaligus dapat membuat adonan menjadi lebih mudah ketika dibentuk menjadi bulat, namun tepung terigu memiliki kekurangan yaitu karena adanya kandungan gluten didalamnya. Kandungan gluten ini dapat menyebabkan masalah serius pada tubuh, 
khususnya yaitu pada penyandang Autism Spectrum Disorder (ASD) dan penyandang celiac disease, sehingga diperlukan bahan campuran bakso yang tidak memiliki kandungan gluten agar dapat dikonsumsi oleh semua kalangan masyarakat. Salah satu bahan campuran bakso yang dapat dikembangkan ialah kacang merah. Produksi kacang merah di Indonesia juga cukup tinggi, hal tersebut sesuai dengan data Badan Pusat Statistik (2019) yang menyatakan produksi kacang merah di Indonesia pada tahun 2018 mencapai 67.876 ton. Pemanfaatan kacang merah ini dapat dijadikan alternatif bahan campuran pada bakso karena kandungan gizinya yang tinggi. Menurut penelitian Wisaniyasa dan Suter (2016) kandungan karbohidrat pada kacang merah sebesar $67,50 \%$, kadar lemak sebesar $6,60 \%$, protein sebesar 13,96\%, dan kandungan serat pangan sebesar $32,23 \%$.

Kacang-kacangan di masyarakat Indonesia banyak dikembangkan dengan cara dibuat menjadi kecambah. Perkecambahan merupakan teknologi sederhana dan sangat murah untuk meningkatkan kualitas pada kacang-kacangan. Proses perkecambahan selain dapat meningkatkan nilai ekonomis dari kacang-kacangan, juga dapat meningkatkan nilai gizi dari kacang-kacangan tersebut. Hal ini didukung oleh hasil penelitian Wisaniyasa dan Suter (2016) bahwa terjadi peningkatan pada kadar protein, kapasitas antioksidan dan serat pangan pada kacang merah selama perkecambahan berlangsung. Selain itu, proses perkecambahan pada kacang-kacangan sangat berperan dalam mengurangi senyawa antigizi yang terkandung di dalamnya.
Salah satu kekurangan dari kecambah yaitu umur simpannya yang relatif sangat singkat. Untuk itu kecambah yang sudah dapat dipanen perlu ditepungkan dengan tujuan untuk memperpanjang umur simpan dan dapat memudahkan untuk dijadikan variasi produk baru. Kandungan karbohidrat yang tinggi pada tepung kecambah kacang merah juga dapat membantu membentuk tekstur yang kompak pada bakso, kandungan karbohidrat tepung kecambah kacang merah sebesar 64,52\% (Wisaniyasa dan Suter, 2016). Selain itu, kandungan gizi yang tinggi khususnya protein pada kacang merah mempunyai potensi sebagai pengganti protein hewani dalam bahan pangan.

Berdasarkan uraian di atas, maka penelitian ini dilakukan dengan tujuan untuk mengetahui pengaruh perbandingan daging ayam dan tepung kecambah kacang merah terhadap karakteristik bakso serta untuk menentukan perbandingan daging ayam dan tepung kecambah kacang merah yang tepat untuk menghasilkan bakso dengan karakteristik terbaik. Melalui penggunaan tepung kecambah kacang merah ini diharapkan dapat menjadi salah satu alternatif untuk membantu masyarakat memulai gaya hidup sehat dengan memanfaatkan bahan nabati terutama komoditi kacang merah secara maksimal.

\section{METODE}

\section{Tempat dan waktu penelitian}

Penelitian ini dilaksanakan mulai dari bulan Agustus 2020 hingga bulan September 2020, dan bertempat di Laboratorium Analisis Pangan dan Laboratorium Pengolahan Pangan, Fakultas 
Teknologi Pertanian, Universitas Udayana yang berlokasi di Gedung Agrokomplek Jl. P.B. Sudirman, Dauh Puri Klod, Denpasar Barat, Kota Denpasar.

\section{Bahan dan alat}

Bahan yang digunakan dalam penelitian ini adalah daging ayam segar, kacang merah segar yang diperoleh dari pasar Kuta, garam, lada bubuk "Ladaku", bawang merah, bawang putih, STPP, putih telur, dan es batu. Dan bahan kimia yang digunakan adalah $\mathrm{H}_{2} \mathrm{SO}_{4}$ bebas nitrogen (Merck), $\mathrm{NaOH}$ PA (Merck), $\mathrm{NaOH}$ teknis, $\mathrm{H}_{3} \mathrm{BO}_{3}$ jenuh (Merck), $\mathrm{HCl} 0,1 \mathrm{~N}$ (Merck), larutan indikator PP, tablet Kjeldahl, hexan, alkohol, aquades, dan etanol $10 \%$.

Alat yang digunakan dalam penelitian ini adalah pemanas Kjeldahl, labu Kjeldahl, alat distilasi lengkap dengan Erlenmeyer ukuran 125 $\mathrm{ml}$, buret $50 \mathrm{ml}$, penggiling, timbangan analitik (Shimadzu ATY224), soxhlet, erlenmeyer $600 \mathrm{ml}$, kertas saring, pinset, spatula, oven (Labo DO 225), texture analyzer, waterbath, desikator, gelas piala, penangas air, keranjang, ayakan 60 mesh, dan corong.

\section{Rancangan percobaan}

Rancangan penelitian yang digunakan adalah Rancangan Acak Lengkap (RAL), dengan perlakuan perbandingan daging ayam dan tepung kecambah kacang merah yang terdiri dari lima taraf, yaitu ;

$\mathrm{B} 0=100 \%$ (daging ayam) $: 0 \%$ (tepung kecambah kacang merah)

B1 $=90 \%$ (daging ayam) $: 10 \%$ (tepung kecambah kacang merah)

B2 $=80 \%$ (daging ayam) $: 20 \%$ (tepung kecambah kacang merah)

B3 $=70 \%$ (daging ayam) $: 30 \%$ (tepung kecambah kacang merah)

B4 $=60 \%$ (daging ayam) : 40\% (tepung kecambah kacang merah)

Masing-masing perlakuan diulang sebanyak 3 kali ulangan, sehingga diperoleh sebanyak 15 unit percobaan. Data yang diperoleh kemudian dianalisis dengan sidik ragam dan apabila terdapat pengaruh antar perlakuan dilanjutkan dengan uji DMRT (Duncan Multiple Range Test) dengan menggunakan IBM SPPS Statistic 25 dengan selang kepercayaan 95\% (Gomez, et al., 1995).

\section{Pelaksanaan penelitian}

Proses pelaksanaan penelitian meliputi beberapa tahapan diantaranya :

\section{Pembuatan kecambah kacang merah}

Tahapan pertama pembuatan kecambah kacang merah yaitu dengan cara melakukan sortasi pada kacang merah terlebih dahulu. Kacang merah segar sebanyak 2.500 gram dicuci menggunakan air bersih dan kacang merah dilakukan perkecambahan dengan cara ditempatkan pada keranjang plastik dengan alas dan tutup daun pisang, serta menggunakan suhu ruangan dan tanpa cahaya matahari. Dalam proses perkecambahan ini perlu pemberian air dengan cara diperciki dengan air bersih sebanyak $10 \mathrm{ml}$ setiap 12 jam, perkecambahan ini dilakukan selama 36 jam. Perkecambahan dilakukan selama kurang 36 jam. Kecambah kacang merah yang sudah dipanen bertambah beratnya menjadi 2.600 gram. 


\section{Pembuatan tepung kecambah kacang merah}

Kecambah kacang merah yang sudah jadi kemudian dilakukan perajangan hingga menjadi lebih kecil, selanjutnya dikeringkan di dalam oven dengan menggunakan suhu $50^{\circ} \mathrm{C}$ selama 20 jam. Kemudian kecambah kering dihaluskan dengan menggunakan penggiling dan diayak menggunakan ayakan 60 mesh. Butiran yang tidak lolos ayakan dihaluskan lagi dengan kecepatan yang lebih tinggi hingga halus. Dari pembuatan tepung kecambah kacang merah ini dihasilkan tepung sebanyak 1.200 gram. Rendemen yang dihasilkan dari pembuatan tepung kecambah kacang ini sebesar $46,15 \%$.

\section{Pembuatan Bakso}

Formulasi pembuatan bakso ini mengacu pada penelitian Amaliah, et al (2016) yang dimodifikasi. Daging ayam dan es dihaluskan menggunakan blender, kemudian daging dicampur dengan garam, bumbu-bumbu yang telah dihaluskan (bawang putih goreng, bawang merah goreng, merica bubuk) kemudian STPP dan putih telur. Adonan yang sudah tercampur kemudian diblender lagi hingga homogen. Kemudian ditambahkan tepung kecambah kacang merah sedikit demi sedikit. Dibentuk adonan bakso menjadi bulatan-bulatan kecil. Bulatan bakso kemudian direbus di air mendidih, bakso yang matang ditandai dengan mengapungnya bola-bola bakso di permukaan air. Kemudian bakso yang sudah matang diangkat dan ditiriskan. Dari 100 gram bahan utama, didapatkan bola-bola bakso kurang lebih sebanyak 11 biji. Adapun formulasi bakso ayam per 100 gram bahan utama dapat dilihat pada Tabel 1.

Tabel 1. Formulasi bakso ayam per 100 gram bahan utama daging ayam

\begin{tabular}{lccccc}
\hline \multirow{2}{*}{ Komposisi Bahan } & \multicolumn{5}{c}{ Perlakuan } \\
\cline { 2 - 6 } & $\mathrm{B} 0$ & $\mathrm{~B} 1$ & $\mathrm{~B} 2$ & $\mathrm{~B} 3$ & $\mathrm{~B} 4$ \\
\hline Daging Ayam Kecambah & $100 \mathrm{~g}$ & $90 \mathrm{~g}$ & $80 \mathrm{~g}$ & $70 \mathrm{~g}$ & $60 \mathrm{~g}$ \\
Tepung Merah & $0 \mathrm{~g}$ & $10 \mathrm{~g}$ & $20 \mathrm{~g}$ & $30 \mathrm{~g}$ & $40 \mathrm{~g}$ \\
Kacang Merah & $4 \mathrm{~g}$ & $4 \mathrm{~g}$ & $4 \mathrm{~g}$ & $4 \mathrm{~g}$ & $4 \mathrm{~g}$ \\
Bawang Putih Goreng & $2,5 \mathrm{~g}$ & $2,5 \mathrm{~g}$ & $2,5 \mathrm{~g}$ & $2,5 \mathrm{~g}$ & $2,5 \mathrm{~g}$ \\
Bawang Merah Goreng & $2,5 \mathrm{~g}$ & $2,5 \mathrm{~g}$ & $2,5 \mathrm{~g}$ & $2,5 \mathrm{~g}$ & $2,5 \mathrm{~g}$ \\
Garam & $0,4 \mathrm{~g}$ & $0,4 \mathrm{~g}$ & $0,4 \mathrm{~g}$ & $0,4 \mathrm{~g}$ & $0,4 \mathrm{~g}$ \\
Lada & $0,3 \mathrm{~g}$ & $0,3 \mathrm{~g}$ & $0,3 \mathrm{~g}$ & $0,3 \mathrm{~g}$ & $0,3 \mathrm{~g}$ \\
STPP & $5 \mathrm{~g}$ & $5 \mathrm{~g}$ & $5 \mathrm{~g}$ & $5 \mathrm{~g}$ & $5 \mathrm{~g}$ \\
Putih Telur & $15 \mathrm{~g}$ & $15 \mathrm{~g}$ & $15 \mathrm{~g}$ & $15 \mathrm{~g}$ & $15 \mathrm{~g}$ \\
Es Batu & & &
\end{tabular}

Sumber: Amaliah, et al. (2016) yang dimodifikasi.

\section{Parameter yang diamati}

Parameter yang diamati pada penelitian ini meliputi kadar air dengan metode pengeringan (Sudarmadji et al., 1997), kadar protein dengan menggunakan metode Kjeldahl (Sudarmadji et al.,
1997), kadar lemak dengan menggunakan metode ekstraksi soxhlet (Sudarmadji et al., 1997), kadar serat kasar dengan menggunakan metode asam dan basa (Sudarmadji et al., 1997), tekstur dengan menggunakan texture analyzer, dan juga sifat 
sensoris yang meliputi uji warna, rasa, tekstur, aroma, dan penerimaan keseluruhan dengan cara uji hedonik (kesukaan) dan uji skoring (Soekarto, 1985).

\section{HASIL DAN PEMBAHASAN}

\section{Hasil Analisis Bahan Baku}

Hasil analisis kadar air, kadar protein, kadar lemak, dan kadar serat kasar daging ayam dan tepung kecambah kacang merah dapat dilihat pada Tabel 2.

Tabel 2. Nilai rata-rata kadar air, kadar protein, kadar lemak, dan kadar serat kasar daging ayam dan tepung kecambah kacang merah.

\begin{tabular}{ccccc}
\hline Perlakuan & $\begin{array}{c}\text { Kadar Air } \\
(\% \mathrm{bb})\end{array}$ & $\begin{array}{c}\text { Kadar Protein } \\
(\% \mathrm{bb})\end{array}$ & $\begin{array}{c}\text { Kadar Lemak } \\
(\% \mathrm{bb})\end{array}$ & $\begin{array}{c}\text { Kadar Serat Kasar } \\
(\% \mathrm{bk})\end{array}$ \\
\hline $\begin{array}{c}\text { Daging ayam } \\
\text { Tepung kecambah } \\
\text { kacang merah }\end{array}$ & $73,98 \%$ & $30,53 \%$ & $2,95 \%$ & $4,86 \%$ \\
\hline
\end{tabular}

\section{Hasil Analisis Bakso}

Nilai rata-rata kadar air, kadar protein, kadar lemak, kadar serat kasar, dan tekstur bakso dapat dilihat pada Tabel 3.

Tabel 3. Nilai rata-rata kadar air, kadar protein, kadar lemak, kadar serat kasar, dan tekstur bakso

\begin{tabular}{cccccc}
\hline $\begin{array}{c}\text { Perlakuan } \\
(\text { daging ayam }: \\
\text { TKKM })\end{array}$ & $\begin{array}{c}\text { Kadar Air } \\
(\% \mathrm{bb})\end{array}$ & $\begin{array}{c}\text { Kadar Protein } \\
(\% \mathrm{bb})\end{array}$ & $\begin{array}{c}\text { Kadar Lemak } \\
(\% \mathrm{bb})\end{array}$ & $\begin{array}{c}\text { Kadar Serat Kasar } \\
(\% \mathrm{bk})\end{array}$ & Tektur (N) \\
\hline $\begin{array}{c}\text { B0 } \\
(100 \%: 0 \%)\end{array}$ & $70,36 \pm 0,35^{\mathrm{d}}$ & $26,70 \pm 5,52^{\mathrm{b}}$ & $10,52 \pm 1,09^{\mathrm{c}}$ & $1,91 \pm 0,34^{\mathrm{a}}$ & $6,40 \pm 0,28^{\mathrm{a}}$ \\
$\begin{array}{c}\text { B1 } \\
(90 \%: 10 \%)\end{array}$ & $68,86 \pm 1,60^{\mathrm{cd}}$ & $23,22 \pm 3,10^{\mathrm{ab}}$ & $8,03 \pm 1,01^{\mathrm{b}}$ & $2,35 \pm 0,54^{\mathrm{a}}$ & $6,63 \pm 1,66^{\mathrm{a}}$ \\
$\begin{array}{c}\text { B2 } \\
(80 \%: 20 \%)\end{array}$ & $66,37 \pm 2,15^{\mathrm{c}}$ & $21,24 \pm 3,43^{\mathrm{ab}}$ & $5,18 \pm 0,11^{\mathrm{a}}$ & $3,88 \pm 0,21^{\mathrm{b}}$ & $9,55 \pm 0,20^{\mathrm{b}}$ \\
$\begin{array}{c}\text { B3 } \\
(70 \%: 30 \%)\end{array}$ & $61,52 \pm 1,36^{\mathrm{b}}$ & $20,71 \pm 0,77^{\mathrm{ab}}$ & $4,94 \pm 0,34^{\mathrm{a}}$ & $6,39 \pm 0,44^{\mathrm{c}}$ & $13,52 \pm 1,85^{\mathrm{c}}$ \\
$\begin{array}{c}\text { B4 } \\
(60 \%: 40 \%)\end{array}$ & $58,60 \pm 1,41^{\mathrm{a}}$ & $17,25 \pm 1,24^{\mathrm{a}}$ & $4,16 \pm 1,05^{\mathrm{a}}$ & $8,49 \pm 1,02^{\mathrm{d}}$ & $18,09 \pm 2,55^{\mathrm{d}}$ \\
\hline
\end{tabular}

Keterangan: Nilai rata-rata yang diikuti oleh huruf yang berbeda pada kolom yang sama menunjukkan perkakuan yang berbeda nyata $(\mathrm{P}<0,05)$; TKKM: Tepung kecambah kacang merah

\section{Kadar Air}

Hasil sidik ragam menunjukkan bahwa perbandingan daging ayam dengan tepung kecambah kacang merah berpengaruh nyata $(\mathrm{P}<0,05)$ terhadap kadar air bakso. Tabel 3 menunjukkan kadar air bakso berkisar antara $58,60 \%$ sampai dengan $70,36 \%$. Kadar air tertinggi pada bakso diperoleh dari perlakuan B0 (100\% daging ayam : $0 \%$ tepung kecambah kacang merah) yaitu 70,36\%, sedangkan kadar air terendah pada bakso diperoleh dari perlakuan B4 (60\% daging ayam : 40\% tepung kecambah kacang merah) yaitu sebesar 58,60\%. Penurunan kadar air ini terjadi seiring dengan meningkatnya penambahan 
tepung kecambah kacang merah, hal ini disebabkan kadar air pada kacang merah dapat menurunkan kontribusi air dari kadar air yang dimiliki daging ayam, dimana kadar air pada daging ayam sebesar $73,98 \%$, sedangkan pada kacang merah sebesar $10,89 \%$. Nilai kadar air maksimal pada bakso sesuai SNI Nomor 3818-2014 adalah 70,0\% bb, hal ini menunjukkan bahwa pada semua perlakuan masih memenuhi syarat.

\section{Kadar Protein}

Hasil sidik ragam menunjukkan bahwa perbandingan daging ayam dengan tepung kecambah kacang merah berpengaruh tidak nyata $(\mathrm{P}<0,05)$ terhadap kadar protein bakso. Tabel 3 menunjukkan kadar protein bakso berkisar antara $17,25 \%$ sampai dengan $26,70 \%$. Nilai kadar protein minimal pada bakso sesuai SNI Nomor 3818-2014 adalah $11,0 \%$ bb. Hal ini menunjukkan bahwa pada perlakuan B2, B3, dan B4 masih memenuhi syarat mutu SNI bakso.

Menurut Rahayu (2016) dalam B, Munassir et al. (2018) menyatakan bahwa komponen protein dalam pembuatan bakso sangat besar peranannya, hal ini dikarenakan protein aktin miosin pada daging ayam dapat berperan dalam pembentukan tekstur bakso yang lembut, kompak dan empuk. Selain itu, protein juga berperan sebagai emulisifier sehingga dapat mengikat air dan lemak dengan baik pada bakso.

\section{Kadar Lemak}

Hasil sidik ragam menunjukkan bahwa perbandingan daging ayam dengan tepung kecambah kacang merah berpengaruh nyata $(\mathrm{P}<0,05)$ terhadap kadar lemak bakso. Tabel 3 menunjukkan kadar lemak bakso berkisar antara
4,16\% sampai dengan 10,52\%. Kadar lemak tertinggi pada bakso diperoleh dari perlakuan B0 (100\% daging ayam : $0 \%$ tepung kecambah kacang merah) yaitu 10,52\% sedangkan kadar lemak terendah pada bakso diperoleh dari perlakuan B4 (60\% daging ayam : $40 \%$ tepung kecambah kacang merah) yaitu sebesar 4,16\%. Penurunan kadar lemak terjadi seiring dengan meningkatnya penambahan tepung kecambah kacang merah, hal ini disebabkan karena kadar lemak tepung kecambah kacang merah lebih rendah daripada kadar lemak daging ayam. Kadar lemak pada tepung kecambah kacang merah sebesar 0,30\%, sedangkan pada daging ayam sebesar $2,95 \%$. Nilai kadar lemak maksimal pada bakso sesuai SNI Nomor 3818-2014 adalah $10,0 \%$ (bb). Hal ini menunjukkan bahwa pada perlakuan B1, B2, B3, dan B4 masih memenuhi syarat mutu SNI bakso.

\section{Kadar Serat Kasar}

Hasil sidik ragam menunjukkan bahwa perbandingan daging ayam dan tepung kecambah kacang merah berpengaruh nyata $(\mathrm{P}<0,05)$ terhadap kadar serat kasar bakso. Tabel 3 menunjukkan kadar serat kasar bakso berkisar antara $1,91 \%$ sampai dengan $8,49 \%$. Kadar serat kasar tertinggi pada bakso diperoleh dari perlakuan B4 (60\% daging ayam : 40\% tepung kecambah kacang merah) yaitu $8,49 \%$, sedangkan kadar serat kasar terendah pada bakso diperoleh dari perlakuan B0 (100\% daging ayam : 0\% tepung kecambah kacang merah) yaitu sebesar $1,91 \%$. Peningkatan kadar serat kasar terjadi seiring dengan meningkatnya penambahan tepung kecambah kacang merah, hal ini karena kandungan serat kasar pada tepung kecambah kacang merah lebih besar 
dibandingkan dengan kadar serat kasar daging ayam. Kadar serat kasar pada daging ayam sebesar $4,86 \%$, sedangkan kadar serat pada tepung kecambah kacang merah sebesar 10,28\%.

Tingginya serat kasar pada tepung kecambah kacang merah tentunya dapat menjadi nilai lebih pada bakso yang dihasilkan. Kadar serat kasar yang tinggi pada tepung kecambah kacang merah diakibatkan karena terjadinya proses perkecambahan sebelum dibuat menjadi tepung. Menurut Indrastati dan Anjani (2016) tepung kacang merah mengandung serat kasar sebesar 5,5$6,1 \%$. Sedangkan pada tepung kacang merah yang sudah dikecambahkan memiliki kadar serat kasar sebesar 10,28\%. Menurut penelitian Benitez et al., (2013) dalam Wisaniyasa dan Suter (2016), proses perkecambahan berpengaruh terhadap kadar serat pangan pada legum. Proses perkecambahan dapat meningkatkan kadar serat pada kacang merah dikarenakan pada proses perkecambahan berlangsung mobilisasi cadangan makanan dari jaringan penyimpanan atau keping biji ke bagian vegetatif, yaitu pada sumbu pertumbuhan embrio atau lembaga sehingga terjadi peningkatan massa pada biji kacang merah selama perkecambahan. Selama terjadi proses perkecambahan ini, cadangan makanan pada biji kacang merah dapat dimanfaatkan oleh manusia untuk dikonsumsi.

\section{Tekstur}

Uji tekstur secara objetif diukur menggunakan alat yang bernama Texture Analyzer. Hasil sidik ragam menunjukkan bahwa perbandingan daging ayam dengan tepung kecambah kacang merah berpengaruh nyata $(\mathrm{P}<0,05)$ terhadap tekstur bakso. Tabel 3 menunjukkan nilai tekstur bakso berkisar antara $6,40 \mathrm{~N}$ sampai dengan $18,09 \mathrm{~N}$. Nilai tertinggi tekstur pada bakso diperoleh dari perlakuan B4 (60\% daging ayam : $40 \%$ tepung kecambah kacang merah) yaitu sebesar $18,09 \mathrm{~N}$, sedangkan nilai terendah tekstur bakso diperoleh dari perlakuan B0 (100\% daging ayam : $0 \%$ tepung kecambah kacang merah) yaitu 6,40 N. Nilai uji tekstur yang kecil menunjukkan tingkat kekenyalan pada suatu bahan. Tingkat kekenyalan tertinggi yaitu pada perlakuan B0, sedangkan pada perlakuan B4 menunjukkan tekstur bakso yang semakin keras, hal ini ditandai dari nilai tekanan alat Texture Analyzer yang menunjukkan angka yang semakin besar.

Menurut Pramuditya dan Yuwono (2014) banyak faktor yang memengaruhi tekstur bakso, antara lain komposisi bakso, proses pembuatan, dan lama pemanasannya. Tingginya karbohidrat pada tepung kecambah kacang merah dapat memengaruhi tekstur pada bakso, menurut penelitian Wisaniyasa dan Suter (2016), kadar karbohidrat pada tepung kecambah kacang merah sebesar $64,82 \%$. Kandungan karbohidrat ini tentu berhubungan erat dengan komponen pati didalamnya yang dapat memengaruhi tekstur bakso yang dihasilkan. Komponen pati pada tepung kecambah kacang merah ini akan mengalami gelatinisasi, dimana pati akan menyerap air selama proses pemanasan, kemudian granula pati tepung kecambah kacang merah ini akan membengkak dan menyerap air yang lebih banyak, sehingga gel lebih mudah rigid ketika mengalami pendinginan (Noranizan et al. 2010 dalam Paliling, 2019). Hal inilah yang menyebabkan tekstur bakso 
menjadi lebih keras ketika diberi perlakuan penambahan tepung kecambah kacang merah yang semakin besar.

\section{Sifat Sensoris}

Sifat sensoris bakso dilakukan degan uji hedonik dan skoring. Uji hedonik dilakukan pada warna, aroma, rasa, tekstur, dan penerimaan keseluruhan. Sedangkan uji skoring dilakukan pada warna, rasa, dan tekstur. Nilai rata-rata uji skoring dan uji hedonik pada warna, aroma, dan rasa bakso dapat dilihat pada Tabel 4. Nilai rata-rata uji hedonik dan skoring tekstur dan penerimaan keseluruhan dapat dilihat pada Tabel 5.

Tabel 4. Nilai rata-rata uji skoring dan uji hedonik pada warna, aroma, dan rasa bakso

\begin{tabular}{cccccc}
\hline Perlakuan & $\begin{array}{c}\text { Hedonik } \\
\text { Warna }\end{array}$ & $\begin{array}{c}\text { Skoring } \\
\text { Warna }\end{array}$ & Hedonik Aroma & Hedonik Rasa & Skoring Rasa \\
\hline B0 $(100 \%: 0 \%)$ & $3,68 \pm 1,46^{\mathrm{a}}$ & $1,24 \pm 0,52^{\mathrm{a}}$ & $4,24 \pm 1,01^{\mathrm{b}}$ & $4,72 \pm 0,84^{\mathrm{d}}$ & $4,72 \pm 0,54^{\mathrm{d}}$ \\
B1 $(90 \%: 10 \%)$ & $3,68 \pm 1,03^{\mathrm{a}}$ & $2,16 \pm 0,55^{\mathrm{b}}$ & $4,48 \pm 0,82^{\mathrm{b}}$ & $4,32 \pm 0,55^{\mathrm{cd}}$ & $3,76 \pm 0,66^{\mathrm{c}}$ \\
B2 $(80 \%: 20 \%)$ & $3,84 \pm 0,85^{\mathrm{a}}$ & $3 \pm 0,70^{\mathrm{c}}$ & $4,44 \pm 0,76^{\mathrm{b}}$ & $3,8 \pm 0,95^{\mathrm{bc}}$ & $3,28 \pm 0,89^{\mathrm{bc}}$ \\
B3 $(70 \%: 30 \%)$ & $3,72 \pm 1,02^{\mathrm{a}}$ & $3,2 \pm 0,91^{\mathrm{c}}$ & $4,32 \pm 0,80^{\mathrm{b}}$ & $3,44 \pm 1,04^{\mathrm{b}}$ & $3,12 \pm 1,05^{\mathrm{b}}$ \\
B4 (60\%:40\%) & $3,64 \pm 1,15^{\mathrm{a}}$ & $3,68 \pm 0,80^{\mathrm{d}}$ & $3,64 \pm 1,22^{\mathrm{a}}$ & $2,56 \pm 1,19^{\mathrm{a}}$ & $2,40 \pm 1,11^{\mathrm{a}}$ \\
\hline
\end{tabular}

Keterangan: Nilai rata-rata yang diikuti oleh huruf yang berbeda pada kolom yang sama menunjukkan perkakuan yang berbeda nyata $(\mathrm{P}<0,05)$; TKKM: Tepung kecambah kacang merah

Tabel 5. Nilai rata-rata uji hedonik dan skoring tekstur dan penerimaan keseluruhan

\begin{tabular}{cccc}
\hline $\begin{array}{c}\text { Perlakuan } \\
\text { (daging ayam : } \\
\text { TKKM) }\end{array}$ & Hedonik Tekstur & Skoring Tekstur & Penerimaan Keseluruhan \\
\hline $\begin{array}{c}\text { B0 } \\
(100 \%: 0 \%)\end{array}$ & $4,56 \pm 0,96^{\mathrm{c}}$ & $2,84 \pm 0,47^{\mathrm{c}}$ & $4,60 \pm 0,91^{\mathrm{d}}$ \\
B1 & $4,20 \pm 0,64^{\mathrm{c}}$ & $2,28 \pm 0,61^{\mathrm{b}}$ & $4,24 \pm 0,77^{\mathrm{d}}$ \\
$\left(\begin{array}{c}90 \%: 10 \%) \\
\text { B2 }\end{array}\right.$ & $3,56 \pm 0,91^{\mathrm{b}}$ & $1,68 \pm 0,69^{\mathrm{b}}$ & $3,64 \pm 0,81^{\mathrm{c}}$ \\
$\begin{array}{c}(80 \%: 20 \%) \\
\text { B3 }\end{array}$ & $3,24 \pm 1,16^{\mathrm{b}}$ & $1,64 \pm 0,81^{\mathrm{a}}$ & $3,04 \pm 0,84^{\mathrm{b}}$ \\
$\left(\begin{array}{c}70 \%: 30 \%) \\
\text { B } 4\end{array}\right.$ & $2,44 \pm 1,26^{\mathrm{a}}$ & $1,44 \pm 0,76^{\mathrm{a}}$ & $2,44 \pm 1,19^{\mathrm{a}}$ \\
$(60 \%: 40 \%)$ & & & \\
\hline
\end{tabular}

Keterangan: Nilai rata-rata yang diikuti oleh huruf yang berbeda pada kolom yang sama menunjukkan perkakuan yang berbeda nyata $(\mathrm{P}<0,05)$; TKKM: Tepung kecambah kacang merah

\section{Warna}

Hasil sidik ragam menunjukkan bahwa perbandingan daging ayam dengan tepung kecambah kacang merah berpengaruh tidak nyata $(\mathrm{P}<0,05)$ terhadap warna bakso dengan uji hedonik. Tabel 4 menunjukkan bahwa rata-rata tingkat kesukaan terendah warna bakso diperoleh pada perlakuan B4 (60\% daging ayam : 40\% tepung kecambah kacang merah) yaitu 3,64 dengan kriteria agak suka, sedangkan nilai tertinggi diperoleh pada perlakuan B2 (80\% daging ayam : $20 \%$ tepung kecambah kacang merah) yaitu 3,84 dengan kriteria agak suka. Sedangkan pada uji skoring, hasil sidik ragam menunjukkan bahwa 
perbandingan daging ayam dengan tepung kecambah kacang merah berpengaruh nyata $(\mathrm{P}<0,05)$ terhadap warna bakso. Tabel 4 menunjukkan bahwa nilai rata-rata skor terendah terhadap warna bakso diperoleh pada perlakuan B0 (100\% daging ayam : $0 \%$ tepung kecambah kacang merah) yaitu 1,24 dengan kriteria sangat tidak merah, sedangkan nilai skor tertinggi diperoleh pada perlakuan B4 (60\% daging ayam : 40\% tepung kecambah kacang merah) yaitu 3,68 dengan kriteria merah yang berbeda nyata dengan perlakuan B0, B1, B2 dan B3. Panelis menyatakan bahwa semakin tinggi penambahan tepung kecambah kacang merah maka warna pada bakso menjadi lebih merah. Hal ini disebabkan karena adanya pigmen antosianin yang dikandung oleh tepung kecambah kacang merah, sehingga memengaruhi warna dari bakso yang dihasilkan.

\section{Aroma}

Hasil sidik ragam menunjukkan bahwa perbandingan daging ayam dengan tepung kecambah kacang merah berpengaruh nyata $(\mathrm{P}<0,05)$ terhadap aroma bakso dengan uji hedonik. Tabel 4 menunjukkan bahwa nilai ratarata tingkat kesukaan terendah aroma bakso diperoleh pada perlakuan B4 (60\% daging ayam : $40 \%$ tepung kecambah kacang merah) yaitu 3,64 dengan kriteria agak suka, sedangkan nilai tertinggi diperoleh pada perlakuan B1 (90\% daging ayam : $10 \%$ tepung kecambah kacang merah) yaitu 4,48 dengan kriteria suka yang tidak berbeda nyata dengan perlakuan B0, B2, dan B3.

\section{Rasa}

Hasil sidik ragam menunjukkan bahwa perbandingan daging ayam dengan tepung kecambah kacang merah berpengaruh nyata $(\mathrm{P}<0,05)$ terhadap rasa bakso dengan uji hedonik. Tabel 4 menunjukkan bahwa nilai rata-rata tingkat kesukaan terendah rasa bakso diperoleh pada perlakuan B4 (60\% daging ayam : 40\% tepung kecambah kacang merah) yaitu 2,56 dengan kriteria biasa, sedangkan nilai tertinggi diperoleh pada perlakuan B0 (100\% daging ayam : 0\% tepung kecambah kacang merah) yaitu 4,72 dengan kriteria suka. Sedangkan pada uji skoring, hasil sidik ragam menunjukkan bahwa perbandingan daging ayam dengan tepung kecambah kacang merah berpengaruh nyata $(\mathrm{P}<0,05)$ terhadap rasa bakso.

Tabel 4 menunjukkan bahwa nilai rata-rata skor terendah terhadap rasa bakso diperoleh pada perlakuan B4 (60\% daging ayam : 40\% tepung kecambah kacang merah) yaitu 2,4 dengan kriteria tidak khas ayam, sedangkan nilai skor tertinggi diperoleh pada perlakuan B0 (100\% daging ayam : $0 \%$ tepung kecambah kacang merah) yaitu 4,72 dengan kriteria sangat khas ayam. Panelis menyatakan bahwa semakin tinggi penambahan tepung kecambah kacang merah maka rasa pada bakso akan kurang disukai, pada perlakuan B4 kurang disukai oleh panelis karena ketika penambahan tepung kecambah terlalu banyak maka rasa bakso semakin langu, sehingga aroma rasa ayam pun juga berkurang.

\section{Tekstur}

Hasil sidik ragam menunjukkan bahwa perbandingan daging ayam dengan tepung kecambah kacang merah berpengaruh nyata $(\mathrm{P}<0,05)$ terhadap tekstur bakso dengan uji hedonik. Tabel 5 menunjukkan bahwa nilai rata- 
rata tingkat kesukaan terendah tekstur bakso diperoleh pada perlakuan B4 (60\% daging ayam : $40 \%$ tepung kecambah kacang merah) yaitu 2,44 dengan kriteria agak tidak suka, sedangkan nilai tertinggi diperoleh pada perlakuan B0 (100\% daging ayam : $0 \%$ tepung kecambah kacang merah) yaitu 4,46 dengan kriteria suka. Sedangkan pada uji skoring, hasil sidik ragam menunjukkan bahwa perbandingan daging ayam dengan tepung kecambah kacang merah berpengaruh nyata $(\mathrm{P}<0,05)$ terhadap tekstur bakso.

Tabel 5 menunjukkan bahwa nilai rata-rata skor terendah terhadap tekstur bakso diperoleh pada perlakuan B4 (60\% daging ayam : 40\% tepung kecambah kacang kacang merah) yaitu 1,44 dengan kriteria tidak kenyal, sedangkan nilai skor tertinggi diperoleh pada perlakuan B0 (100\% daging ayam : $0 \%$ tepung kecambah kacang merah) yaitu 2,84 dengan kriteria kenyal. Tekstur bakso yang tidak kenyal pada perlakuan B4 disebabkan karena memiliki kadar protein yang rendah. Hal ini disebabkan karena daging ayam yang ditambahkan semakin sedikit sehingga prosentase protein semakin mengecil. Protein yang tinggi pada daging ayam dapat mengikat air sehingga hal ini dapat memengaruhi kekenyalan pada bakso.

Keberadaan kadar air dalam bakso memengaruhi tingkat keempukan bakso, hal ini dikarenakan kadar air memengaruhi mutu bahan pangan yaitu daya terima, kesegaran, dan juga kestabilan daya simpan dari produk. Menurut Genisa (2015) kadar air dalam bahan pangan juga memengaruhi pembentukan sifat organoleptik suatu produk, kadar air akan berpengaruh terhadap kenampakan, tekstur, dan cita rasa. Selain itu, kekenyalan pada bakso juga disebabkan oleh kandungan pati pada bahan campuran bakso, kandungan pati yang semakin tinggi menyebabkan tekstur bakso semakin keras.

\section{Penerimaan Keseluruhan}

Hasil sidik ragam menunjukkan bahwa perbandingan daging ayam dengan tepung kecambah kacang merah berpengaruh nyata $(\mathrm{P}>0,05)$ terhadap penerimaan keseluruhan bakso dengan uji hedonik. Tabel 5 menunjukkan bahwa nilai rata-rata tingkat kesukaan terendah tekstur bakso diperoleh pada perlakuan B4 (60\% daging ayam : $40 \%$ tepung kecambah kacang merah) yaitu 2,44 dengan kriteria agak tidak suka, sedangkan nilai tertinggi diperoleh pada perlakuan B0 (100\% daging ayam : $0 \%$ tepung kecambah kacang merah) yaitu 4,60 dengan kriteria suka.

\section{KESIMPULAN DAN SARAN}

\section{Kesimpulan}

Perbandingan daging ayam dengan tepung kecambah kacang merah berpengaruh nyata terhadap kadar air, kadar lemak, kadar serat kasar, dan tekstur bakso. Serta pada uji sensoris berpengaruh nyata pada warna (skoring), aroma (hedonik), rasa (hedonik dan skoring), tekstur (hedonik dan skoring), dan penerimaan keseluruhan (hedonik), sedangkan tidak berpengaruh nyata terhadap kadar protein dan warna (hedonik). Bakso dengan perbandingan 90\% daging ayam dan $10 \%$ tepung kecambah kacang merah menghasilkan bakso dengan karakteristik terbaik, yaitu dengan kriteria kadar air 68,86\%, kadar protein 23,22\%, kadar lemak 8,03\%, kadar serat kasar $32,35 \%$, tekstur $6,63 \mathrm{~N}$, uji sensoris 
wana, aroma, rasa, tekstur, dan penerimaan keseluruhan disukai.

\section{Saran}

Berdasarkan hasil penelitian disarankan untuk menggunakan perbandingan $90 \%$ daging ayam dan $10 \%$ tepung kecambah kacang merah dalam pembuatan bakso dengan campuran tepung kecambah kacang merah.

\section{DAFTAR PUSTAKA}

Amaliah S., A Munandar., S Haryati. (2016). Pengaruh penambahan bubur rumput laut (Kappaphycus alvarezii) terhadap karakteristik bakso ikan payus (Elops hawaiensis). Jurnal Perikanan dan Kelautan.

Andarwulan, N., F Kusnandar., D Herawati. 2011. Analisis Pangan. Dian Rakyat. Jakarta.

B, Munassir. Nurhaeda. Irmayani. (2018). Kandungan Kadar Air dan Kadar Protein pada Bakso Ayam Broiler dengan Putih Telur Sebagai Bahan Pengenyal pada Konsentrasi yang Berbeda. Jurnal Bionature, Volume 19, Nomor 2

Benitez, V., S. Cantera, Y. Aguilera, E. Molla, R. M.Esteban, MF. Diaz, M.A.A. Cabrejaz. (2013). Impact of germination on starch, dietary fiber and physicochemical properties in non-conventional legumes. Journal of Food Research International. 50 (1): 64-69

Badan Pusat Statistik Indonesia. (2019). Statistik Tanaman Sayuran dan Buah-Buahan Semusim Indonesia. Jakarta: BPS RI.

Genisa, Jalil. Sukendar, Nandi K. Langkong, Jumriah. Abdullah, Nurlaela. (2015). Analog Bakso Sehat Dari Protein Kacang Merah (Phaseolus vulgaris L). Jurnal AgriTechno Vol. 8, No. 1

Gomez, K. A. dan A. A. Gomez. (1995). Prosedur Statistik Untuk Penelitian Pertanian. UI Press. Jakarta.

Indrastati, Nandia, dan Anjani, Gemala. 2016. Snack Bar Kacang Merah Dan Tepung Umbi Garut Sebagai Alternatif Makanan Selingan
Dengan Indeks Glikemik Rendah. Journal of Nutrition College. Volume 5, Nomor 4

Noranizam, M. A., Dzulkifly, M.H and Rusly, A.R. (2010). Effect of heat treatment on the physico-chemical properties of strarch from different botanical sources. International Food Research Journal 17:127-135

Paliling, Iin $\mathrm{P} \mathrm{H}$. Metusalach. Amir, Nursinah. (2019). Kualitas Dan Kesukaan Bakso Ikan Nila (Oreochromis niloticus) Dengan Penambahan Ekstrak Karotenoid Dari Cangkang Udang Putih (Litopenaeus vannamei). Jurnal IPTEKS PSP. Vol. 5 (10)

Pramuditya, Galih., dan Yuwono, Sudarminto S. (2014). Penentuan Atribut Mutu Tekstur Bakso Sebagai Syarat Tambahan Dalam Sni Dan Pengaruh Lama Pemanasan Terhadap Tekstur Bakso. Jurnal Pangan dan Agroindustri Vol. 2 No 4 p.200-209

Rahayu. (2016). Fungsi Bahan Pengisi Bakso. Universitas Muhammadiyah. Semarang.

Rahmadani, K. I. (2019). Pengaruh Rasio Daging Ayam Broiler (Gollus domesticus) dengan Jamur Merang (Volvariella volvacea S.) terhadap Karakteristik Tum ayam. Jurnal Ilmu dan Teknologi Pangan. 8(3):303-312.

Soekarto, S. T. (1985). Penilaian Organoleptik (untuk Industri Pangan dan Hasil Pertanian). Penerbit Bharata Karya Aksara., Jakarta.

Sudarmadji, S., B. Haryono dan Suhardi. (1997). Prosedur Analisis Untuk Bahan Makanan dan Pertanian. Liberty., Yogyakarta.

Untoro, N.S., Kusrahayu., B, E, Setiani. (2012). Kadar air, kekenyalan, kadar lemak dan citarasa bakso daging sapi dengan penambahan ikan bandeng presto (Channos channos F). Animal Agriculture Journal. 1(1): 567- 583.

Wisaniyasa, N, W, dan I, K, Suter. (2016). Kajian Sifat Fungsional dan Kimia Tepung Kecambah Kacang Merah (Phaseolus vulgaris L). Media Ilmiah Teknologi Pangan. 3(1):26-34. 